\title{
Corporate Governance and Firm Performance: An Empirical Analysis of Manufacturing Listed Firms in Ghana
}

\author{
Beatrice Sarpong-Danquah ${ }^{1}$, Prince Gyimah ${ }^{2}$, Richard Owusu Afriyie ${ }^{1} \&$ Albert Asiamah $^{3}$ \\ ${ }^{1}$ Kwame Nkrumah University of Science and Technology, Accounting and Finance Department, Kumasi, Ghana \\ ${ }^{2}$ University of Education, Winneba, Kumasi-Campus, Department of Accounting Studies Education, Ghana \\ ${ }^{3}$ Kwame Nkrumah University of Science and Technology, Dairy Beef and Cattle Research Centre, Boadi, Ghana \\ Correspondence: Prince Gyimah, University of Education, Winneba, Kumasi-Campus, Department of Accounting \\ Studies Education, Ghana. E-mail: princegyima@yahoo.co.uk
}

Received: May 9, 2018

Accepted: June 1, 2018

Online Published: June 7, 2018

doi:10.5430/afr.v7n3p111

URL: https://doi.org/10.5430/afr.v7n3p111

\begin{abstract}
This paper assesses the effect of corporate governance on the financial performance of manufacturing firms in a developing country. Specifically, the paper investigates whether gender diversity, board independence, and board size affects return on asset (ROA) and return on equity (ROE) of manufacturing listed firms in Ghana. We use the generalized least squares (GLS) panel regression model to analyze the dataset of 11 listed manufacturing firms from 2009-2013. Our result reveals an insignificant representation of women on boards. Also, the empirical result shows that board independence and board gender diversity have significant positive effect on ROE and ROA. However, there is no statistical significant relationship between board size and firm performance (ROE and ROA). We suggest that manufacturing firms should appoint female board members as well as outside directors on their boards as this can make significant contribution to firm's performance. Our study provides the first comprehensive explicit exposition of corporate governance-performance nexus using data from the manufacturing sector in Ghana.
\end{abstract}

Keywords: manufacturing firms, board independence, gender diversity, board size, firm performance, Ghana

\section{Introduction}

Corporate governance has gained pre-eminence in the late 1990's and early 2000 following the spectacular failure of large organizations including Fanny Mae, Tyco, Northern Rock, Enron, Adelphia, Arthur Anderson, Freddy Mac, WorldCom, Goldman Sachs, Marconi, Parmalat, Lehman Brothers and Yukos (Duke \& Kankpang, 2011). This is not different in Ghana as similar failure could be seen in the cases of Ghana Airway Limited, Juapong Textiles Limted, Capital Bank, GT Bank, Jesta Motors and DKM Microfinance. Most reported cases of corporate failure are attributed to corporate governance practices (Appiah, 2013). Thus, corporate governance research has been a crucial issue of discussion over the last three decades.

Many developed and developing countries are putting measures in place to ensure that corporate failure becomes a thing of the past by making laws for companies that are operating within their jurisdiction to comply with corporate governance principles. For instance, the United States of America (USA) in 2002 developed the Sarbanes Oxley Act as a rule-based approach on corporate governance for companies operating in USA. Sri Lanka in 2003 issued voluntary code of best practices and this was made a compulsory guideline in 2007 for all listed firms operating in the country (Velnampy, 2013). This led to the development of strict measures by regulatory bodies such as the Securities Exchange Commission (SEC), Committee of Sponsoring Organizations (COSO), and International Financial Corporation, to punish wrong doers and safeguard stakeholder's interest. Thus, on a global scale, the role of corporate governance has become significant for firm performance (Donaldson, 2003). According to studies by various researchers, the market value in the long term and the profitability of firms can be maximized by good corporate governance practices (Khumani e $t$ a l., 1998). Banerjee $e$ t a l. (2009) also state that in emerging and transitioning economies, good corporate governance is necessary in all economic transactions. Hence the need to develop good corporate governance in every country has become necessary.

Does good corporate governance necessarily increase firm value? Increasing number of researches have been carried out on corporate governance globally. Some studies have shown a positive relationship (Bebchuk \& Weisbach, 2009), some have shown a negative relationship (Bøhren \& Strøm, 2010) and others have shown no relationship (Darmadi, 
2011; Alvarado et al., 2011) between c orporate governance and firms' performance (Ghabayen, 2012). The subject, however, is evolving in emerging markets like Ghana. The study therefore uses data from the manufacturing sector of Ghana to test the nexus between corporate governance and firm performance. The paper contributes to extant debate on the nexus of corporate governance and firm performance as well as serve as a starting point for further research in the context of manufacturing firms in developing countries. Our study is the first comprehensive explicit exposition of corporate governance-performance nexus using data from the manufacturing sector of Ghana.

The paper is organized as follows. Section 2 reviews literature. Section 3 shows the methodology of the study. Section 4 presents and discusses the results of the empirical analysis. Section 5 concludes.

\section{Literature Review}

\subsection{Theoretical Foundation}

Two main governance theories, resource dependency theory and agency theory help explain corporate governance and firm's performance. The next sections discuss briefly each theory in turn.

\subsubsection{Resource Dependency Theory}

Resource dependency theory is mainly about the accessibility of resources such as capital and expertise by firms. Pfeffer (1973) stipulates that board of directors that have adequate resources effectively affect firm's performance. Meanwhile, Haniffa and Hudaib (2006) contend that resource dependency theory mostly favour boards that have more independent directors. In particular, Kiel and Nicholson (2003) assert that independent directors' wider expertise, knowledge and network with external environment can help increase capital, business and political contacts, as well as proper financial information. Thus, independent directors can improve the accessibility of resources that require inexpensive inputs or resources and hence affects the financial performance of firm positively.

\subsubsection{Agency Theory}

Agency theory stipulates that the ownership and control of firms are vested in different individuals, there exists a conflict of interest between principal and agent (Aguilera et al., 2008). According to Williamson (1975), managers may seek to fulfil their own self-interests as opposed to shareholder's interest or worth. Thus, managers cannot be trusted, even though they are often thought to be rational. In line with this school of thought, Jensen and Meckling (1976) assert that managers do not constantly pursue shareholders interest, and corporate governance is therefore an effective tool in solving the agency problem with the establishment of board.

\subsection{Empirical Review}

It is clear that both resource dependency and agency theories normally predict a positive causal relationship between corporate governance and firm's performance. However, this relationship is an issue of debate in literature since researchers find varying results. The next sections give some empirical results of three corporate governance variables namely - board size, board independence, and gender diversity on firm performance used in our study.

\subsubsection{Board size and Firm Performance}

A research work carried out by Goodstein et al. (1998) find that size of board and performance have significant positive relationship. Also, a study done by Makailu, and Garba (2005) on dataset of 93 Nigerian Listed firms shows that board size and profitability (return on equity) have positive relationship. Moreover, Saravanan (2012) research work in India on manufacturing firm shows that size of board and financial performance have significant positive relationship. However, Yermack (1996) finds that there is a negative relationship between board size and firm performance (Tobin's Q) on dataset of 452 top level US public firms. Also, Eisenberg et al. (1998) research work on 879 small and middle level firms find an adverse relationship between board size and return on asset (ROA).

\subsubsection{Board independence and Firm Performance}

Gordini (2012) reports that non-executive directors and performance (ROA and ROE) have positive relationship among 950 Italian companies. Bebchuk and Weisbach (2010) purport that a high percentage of outside director's increased board independence, and their results also show that board independence positively affects firm performance. Also, Khan and Awan (2012) review that ROE, Tobin's q and ROA (performance measures) and non-executive directors have significant positive relationship. These positive relationships show that outside directors can effectively monitor the activities of managers and this agrees the opinion of resource dependency and agency theories. However, per the works carried out by Yermack (1996), Knoeber and Agrawal (1996), and Bozec (2005), a negative relationship is found between performance and independent directors. Meanwhile, Baysinger and 
Hoskinsson (1990), Hermalin and Weisbach (1991), Kumar and Singh (2012) report no relationship between firm performance and independent directors.

\subsubsection{Gender Diversity and Firm Performance}

Empirical results of Carter et al. (2003) on Fortune 500 committees between the year 1998 and 2002 review that gender diversity and performance (Tobin's Q) have significant positive relationship. Also, Catalyst (2004) finds that majority of females on board positively affect return on invested capital, return on investment (ROI), return on equity (ROE), compared to few female on board among 500 US companies. Kang et al. (2009) also report similar findings; they find that board with majority females positively increases supervision, control and performance of firms. Moreover, Parrotta and Smith (2013) did research on Danish companies from 1997 to 2007 and find that female board members positively affects return on equity (ROE) of Danish firms. ThaoThi (2014) also find that the proportion of females on board and performance have significant positive relationship of listed firms in Vietnam. Surprisingly, Bøhren and Strøm (2010) report a high negative significant relationship between gender diversity and firm performance using Tobin's Q, ROA and market return on stock. Meanwhile, Alvarado et al. (2011), and Darmadi (2011) report that there is no significant relationship between gender diversity and firm performance.

\section{Methodology}

We employ a balanced panel dataset of 11 manufacturing firms listed on Ghana Stock Exchange (GSE) over a period of five (5) years yielding 55 firm year observations. The 11 manufacturing firms were conveniently chosen on accessibility and availability of their annual financial reports within the period under-study (2009-2013). Variables used for the analysis include financial performance and corporate governance measures. Financial performance is operationalized using two commonly based accounting measures, return on asset (ROA) and return on equity (ROE). The corporate governance measures include gender diversity, board independence and board size. Firm age and firm size are also included as control variables.

Panel regression model that pools observation on a cross sectional unit over several time periods is used for the study since it helps to ascertain unbiased and consistent estimate. To avoid the problem of heteroscedasticity and autocorrelation, the generalized least squares (GLS) panel regression model is used to analyze the relationship between the corporate governance variables, firm performance measures and control variables used in the study.

The following regression equation are estimated for the empirical analysis:

$$
\begin{aligned}
\text { ROE }_{i t}= & \beta_{0}+\beta_{1} \text { Gender }_{i t}+\beta_{2} \text { Board size }_{i t}+\beta_{3} \text { Board independence }_{i t}+\beta_{4} \text { Firm size }_{i t}+ \\
& \beta_{5} \text { Frim age }_{i t}+\varepsilon_{i t} \\
\text { ROA }_{i t}= & \beta_{0}+\beta_{1} \text { Gender }_{i t}+\beta_{2} \text { Board size }_{i t}+\beta_{3} \text { Board independence }_{i t}+\beta_{4} \text { Firm size }_{i t}+ \\
& \beta_{5} \text { Frim age }_{i t}+\varepsilon_{i t}
\end{aligned}
$$

Where,

ROA (Return on Assets) equals ratio of earnings before interest and tax (EBIT) and total assets.

ROE (Return on Equity) equals ratio of earnings before interest and tax (EBIT) and total equity.

Gender equals the proportion of female directors on the board.

Board size equals the number of people on the board.

Board independence equals the number of non-executive directors on the board.

Firm size equals the natural logarithm of total assets of the firms.

Firm age equals the number of years of firm existence.

$\beta_{0}$ represents constant.

$\beta_{1}$ to $\beta_{5}$ are the coefficients, slope or parameter estimates for the independent and control variables.

Ei represents the error term. 


\section{Empirical Results and Discussion}

\subsection{Descriptive Statistics}

Table 1 shows the descriptive statistics of the dependent and explanatory variables for the study. From Table 1, it is indicated that boards size is fairly isolated with a minimum of four (4) and a maximum of twelve (12) board members. On the average, the size of boards of manufacturing firms in Ghana is approximately eight (8) indicating the significance such firms place on corporate governance.

Also, our result shows that in Ghana, majority of directors (59 percent) on boards of manufacturing firms are independent which is similar with 58 percent reported by Klein (1998) in the US. Regarding board gender diversity, an average of 12.9 percent females are present on boards of manufacturing firms in Ghana. Our results reveal that the maximum representation of females on manufacturing firms' boards is four (4) while some firms (24 percent) do not have a single female on their boards.

Also, at a minimum of 6 and a maximum of 80, the average manufacturing firm has existed for over 43 years, implying that sample firms are relatively stable. With a minimum asset size of 1.3 million Ghana Cedis and a maximum of 29.8 billion Ghana Cedis, the average asset size is however 7.5 billion Ghana Cedis. In terms of ROE and ROA, the results show that there is a huge gap in terms of profitability among the manufacturing listed firms during the years under review. This could be the extraordinary large losses incurred by firms in a particular fiscal period. The result also indicates that as some of the firms are doing extremely well with higher return on equity at 52 percent, others are making abnormal losses at -80.7 percent.

Table 1. Descriptive statistics

\begin{tabular}{llllll}
\hline Variables & Obs. & Mean & SD & Min & Max \\
\hline Board size & 55 & 7.96 & 2.32 & 4.00 & 12.00 \\
Gender & 55 & 0.1293 & 0.0996 & 0.00 & 0.40 \\
Board Independence & 55 & 0.5896 & 0.2613 & 0.125 & 0.875 \\
Firm age & 55 & 43.909 & 17.766 & 6.00 & 80.00 \\
Firm size & 55 & $7.48 \mathrm{e}+07$ & $7.57 \mathrm{e}+07$ & 1314378 & $2.98 \mathrm{e}+08$ \\
ROA & 55 & 0.1001 & 0.1425 & -0.2681 & 0.399 \\
ROE & 55 & -1.8518 & 11.1926 & -80.692 & 0.524 \\
\hline
\end{tabular}

Note: $\mathrm{ROE}$ (Return on equity), ROA (Return on assets)

\subsection{Multicollinearity Test}

The study uses Pearson correlation matrix and vector inflation factor (VIF) to test the probable degree of collinearity among the variables. Table 2 and Table 3 show the results. The correlation among the variables may affect the efficacy of the estimated coefficients. Table 2 depicts that the predicting variables represented by board size and board independence are negatively correlated with firm age though the correlation is weak.

Similarly, gender diversity and firm size have a positively weak correlation with firm age. Generally, the correlation coefficients are not significantly large to cause multicollinearity problems in the regressions. Again, referring to Table 3 (results of VIF), the values of the VIF of all the variables are less than 10 (the accepted threshold) and this shows a clear indication that the variables are not suffering from the problem of multicollinearity.

Table 2. Pearson's Correlation for the dependents and independent Variables for the Study

\begin{tabular}{lllllllll}
\hline & Variables & 1 & 2 & 3 & 4 & 5 & 6 & 7 \\
\hline 1 & ROA & 1.0000 & & & & & & \\
2 & ROE & 0.0292 & 1.0000 & & & & & \\
3 & Firm age & 0.3055 & 0.1400 & 1.0000 & & & & \\
4 & Board size & -0.1462 & -0.2866 & -0.1733 & 1.0000 & & & \\
5 & Gender & 0.2606 & 0.0853 & 0.4749 & 0.0293 & 1.0000 & & \\
6 & Board independence & 0.1498 & -0.1586 & -0.3340 & 0.1458 & -0.3723 & 1.0000 & \\
7 & Firm size & -0.0382 & -0.2336 & 0.2456 & 0.6849 & 0.1505 & 0.3180 & 1.0000 \\
\hline
\end{tabular}


Table 3. Variance Inflation Factor (VIF) of ROE and ROA

\begin{tabular}{llllll}
\hline ROE & VIF & $\mathbf{1 / V I F}$ & ROA & VIF & 1/VIF \\
\hline Firm size & 7.43 & 0.13 & Firm size & 4.51 & 0.22 \\
Firm age & 7.14 & 0.14 & Firm age & 3.95 & 0.25 \\
Board independence & 4.19 & 0.24 & Board independence & 2.93 & 0.34 \\
Board size & 2.54 & 0.39 & Board size & 1.99 & 0.50 \\
Gender & 1.30 & 0.77 & Gender & 1.26 & 0.79
\end{tabular}

$\begin{array}{llll}\text { Mean VIF } & 4.52 & \text { Mean VIF } & 2.93\end{array}$

\subsection{Regression Results}

Table 4 shows the regression results for model 1. From Table 4, our results show that board independence and return on equity (ROE) have positive significant relationship at 1 percent significance level. Thus, the existence of outside directors in terms of their strict supervision, advice, expertise in financial, legal and other areas and their external influences positively affects the financial performance of manufacturing listed firms in Ghana. This means that as the number of non-executive director's increases, manufacturing firms tend to perform better. Our result agrees with the opinions of the advocates of both resource dependency and agency theories that postulate that board indepence and performance of firms have a positive causal relationship. Particularly, Jensen and Meckling (1976) assert that executive directors, by their virtue of status possess much information that are likely to collude with managers and make decisions against shareholders' interest or worth. They again propose that outside directors in neutral position, act as supervisors and this can help eliminate principal-agency problem as evident through the positive relationship in Table 4. Our result is also consistent with the findings of Bebchuk and Weisbach (2009); Gordini (2012), and Khan and Awan (2012) who asserts that board independence has significant positive relation with firm performance.

Our empirical results again show that gender diversity has a positive significant relationship with ROE at 1 percent significance level. Thus, as the number of females on board increases firms' ROE tend to improve. The empirical evidence supports the view that females on board diversify membership on the board and this can massively increase the financial performance of firms. A plausible reason for this positive association is the assertion made by Smith $e t$ al. (2006) who argue that females on board provide better understanding of market indicators as compared to males. Hence, they can bring better images in the perception of the community for a firm and this can positively contribute to firms' performance. The positive relationship reaffirms the proposition of the resource dependency theorist who predict a positive causal relationship between corporate governance indicators and firm performance. Carter et al. (2003); Catalyst (2004); Kang et al. (2009); and Parrotta and Smith (2013) find similar results using ROI, ROE and ROA respectively.

Also, we find that there is no statistical relationship between board size and ROE. This contradict large extant literature that found either a positive relationship (Goodstein et al., 1998; Makailu \& Garba, 2005, Saravanan, 2012) or a negative relationship (Yermack, 1996 and Eisenberg et al., 1998) between board size and firm performance. Interestingly, the result shows that there is no statistical relationship between firm age and firm size.

\subsection{Robustness Check}

To obtain a robust estimate, ROA is used as the dependent variable. We find a positive significant relationship between board independence and ROA at 1 percent significance level (see Table 5) which is robust to model 1 above. Although our result in model 1 above shows a positive significant relationship between board gender diversity and firm performance (measured by ROE), it is not robust to model two as indicated in Table 5 below. We thus find no significant statistical relationship between gender and ROA. Board size does not have any significant statistical relationship with firm performance (ROA), thus robust to results in model 1 above. This implies that the size of the board does not matter, however, the constituent, or the characteristics of people in the board room is a matter of importance since board independence and gender diversity seems to predict performance significantly. Contrary to results in model 1, firm age and size respectively has positive and negative significant relationships with ROA (see Table 5) which is consistent with (Anderson \& Reeb, 2004; Jensen \& Meckling, 1976) who predicts similar relationships. 
Table 4. GLS Panel regression model results (ROE)

\begin{tabular}{llll}
\hline Variable & Coefficient & Standard Error & Prob. \\
\hline Board size & -0.127803 & 0.648262 & 0.844 \\
Gender & 0.966228 & 0.298958 & 0.001 \\
Board independence & 1.032930 & 0.377556 & 0.006 \\
Firm age & 1.132340 & 0.999124 & 0.257 \\
Frim size & -0.002744 & 0.195874 & 0.989 \\
Constant & -3.276187 & 2.076702 & 0.115
\end{tabular}

Number of Observation

55

Wald chi ${ }^{2}$

24.86

Prob. $\left(\mathrm{Chi}^{2}\right)$

0.0001

Table 5. GLS Panel regression model results (ROA)

\begin{tabular}{llll}
\hline Variable & Coefficient & Standard Error & Prob. \\
\hline Board size & 0.179966 & 0.611121 & 0.794 \\
Gender & 0.414122 & 0.320548 & 0.257 \\
Board independence & 2.281145 & 0.337555 & 0.000 \\
Firm age & 3.990067 & 0.813601 & 0.000 \\
Frim size & -0.694810 & 0.162385 & 0.000 \\
Constant & -3.380837 & 1.998738 & 0.091
\end{tabular}

Number of Observation

Wald $\mathrm{Chi}^{2}$

Prob. $\left(\mathrm{Chi}^{2}\right)$
55

45.9

0.0000

\section{Conclusion}

The significance of corporate governance has been argued commonly among public listed firms without paying attention to specific industries. Our current paper emphases on the importance of corporate governance in the manufacturing sector of Ghana. We find that board independence and gender diversity of boards have positive significant effect on the performance of manufacturing listed firms in Ghana. We generally suggest that the implementation of corporate governance principles has some imperative implications for manufacturing firms in Ghana. Our study notes that board independence ensures better management practices through boards exerting much needed pressure, greater opportunities, stronger internal auditing, and strategic outlook through external directors.

We find underrepresentation of female on boards of manufacturing firms at 12.9 percent and yet resulted in significant positive relationship with firm performance (ROE). Although the positive relationship between female on board and firm performance was not statistically robust when ROA is used as performance indicator. From our result, there is absolutely no evidence that an increased proportion of females in the boardroom has a negative effect on firms' performance. Again, we find no link between board size and firm performance. This implies that the size of boards today does not really matter, however the caliber of people on the board is a matter of importance since board independence and gender diversity had a significant influence on the firm performance. Our study also finds empirical evidence to support the view that firm size and age can affect the performance of the firm significantly.

Based on our empirical findings, we propose that firms should appoint female board members in the manufacturing sector of Ghana because the females can make significant contribution to firm's performance. Again, firms should ensure the appointment of outside directors on their boards as it contributes positively to firm's performance.

Our study is limited to Ghanaian manufacturing firms listed on the Ghana Stock Exchange (GSE), hence findings of the study cannot be generalized. We therefore suggest that future studies should consider both listed and non-limited 
manufacturing firms. Again, future studies should consider other sub-regions in the Africa continent and if possible, a comparative study of emerging economies.

\section{References}

Aguilera, R. V., Filatotchev, I., Gospel, H., \& Jackson, G. (2008). An organizational approach to comparative corporate governance: Costs, contingencies, and complementarities. Organization Science, 19(3), 475-492. https://doi.org/10.1287/orsc.1070.0322.

Alvarado, N. R., Briones, J. L., \& Ruiz, P. F. (2011). Gender diversity on boards of directors and business success. Investment Management and Financial Innovations, 8(1), 199-209.

Anderson, R. C., \& Reeb, D. M. (2004). Board composition: Balancing family influence in S\&P 500 firms. Administrative science quarterly, 49(2), 209-237.

Appiah, K.O. (2013). Corporate Governance and Corporate Failure: Evidence from Listed UK Firms, PhD Thesis, Loughborough University, UK.

Banerjee, A., Gakam, S., Pathanyak, M. \& Simba, S. (2009). Corporate governance and market value, preliminary evidence from Indian companies. Retrieved from www.standardsandpoo.s.com.

Baysinger, B., \& Hoskisson, R. E. (1990). The composition of boards of directors and strategic control: Effects on corporate strategy. Academy of Management Review, 15(1), 72-87. https://doi.org/10.5465/amr.1990.4308231.

Bebchuk, L. A., \& Weisbach, M. S. (2010). The state of corporate governance research. The Review of Financial Studies, 23(3), 939-961. https://doi.org/10.1093/rfs/hhp121.

Bebchuk, L. A., \& Weisbach, M. S. (2010). The state of corporate governance research. The Review of Financial Studies, 23(3), 939-961. https://doi.org/10.1093/rfs/hhp121.

Bøhren, Ø., \& Strøm, R. Ø. (2010). Governance and politics: Regulating independence and diversity in the board room. Journal of Business Finance \& Accounting, 37(9-10), 1281-1308. https://doi.org/10.1111/j.1468-5957.2010.02222.x.

Bozec, R. (2005). Boards of directors, market discipline and firm performance. Journal of Business Finance \& Accounting, 32(9-10), 1921-1960. https://doi.org/10.1111/j.0306-686X.2005.00652.x.

Carter, D. A., Simkins, B. J., \& Simpson, W. G. (2003). Corporate governance, board diversity, and firm value. Financial review, 38(1), 33-53. https://doi.org/10.1111/1540-6288.00034.

Catalyst (2004). The Bottom Line: Connecting Corporate Performance and Gender Diversity, Catalyst: New York.

Dalton, D. R., Daily, C. M., Ellstrand, A. E., \& Johnson, J. L. (1998). Meta-analytic reviews of board composition, leadership structure, and financial performance. Strategic management journal, 19(3), 269-290. https://doi.org/10.1002/(SICI)1097-0266(199803)19:3\%3C269::AID-SMJ950\%3E3.0.CO;2-K.

Darmadi, S. (2011). Board compensation, corporate governance, and firm performance in Indonesia. Retreived from https://ssrn.com/abstract=1907103 or http://dx.doi.org/10.2139/ssrn.1907103.

Donaldson, T. (2003). Corporate governance. The International Encyclopedia of Ethics, 1113-1119. https://doi.org/10.1002/ 9781444367072.wbiee458.

Eisenberg, T., Sundgren, S., \& Wells, M. T. (1998). Larger board size and decreasing firm value in small firms. Journal of financial economics, 48(1), 35-54. https://doi.org/10.1016/S0304-405X(98)00003-8.

Ghabayen, M. A. (2012). Board characteristics and firm performance: Case of Saudi Arabia. International Journal of Accounting and Financial Reporting, 2(2), 168.

Gordini, N. (2012). The impact of outsiders on small family firm performance: Evidence from Italy. World Journal of Management, 4(2), 14-35.

Haniffa, R., \& Hudaib, M. (2006). Corporate governance structure and performance of Malaysian listed companies. Journal of Business Finance \& Accounting, 33(7-8), 1034-1062. https://doi.org/10.1111/j.1468-5957.2006.00594.x.

Hermalin, B. E., \& Weisbach, M. S. (1991). The effects of board composition and direct incentives on firm performance. Financial management, 20(4), 101-112. https://doi.org/10.2307/3665716.

Jensen, M. C., \& Meckling, W. H. (1976). Theory of the firm: Managerial behavior, agency costs and ownership structure. Journal of financial economics, 3(4), 305-360. https://doi.org/10.1016/0304-405X(76)90026-X 
Joe Duke, I. I., \& Kankpang, K. A. (2011). Linking corporate governance with organizational performance: New insights and evidence from Nigeria. Global Journal of Management and Business Research, 11(12). 47-58.

Kang, H., Cheng, M., \& Gray, S. J. (2007). Corporate governance and board composition: Diversity and independence of Australian boards. Corporate Governance: An International Review, 15(2), 194-207. https://doi.org/10.1111/j.1467-8683.2007.00554.x.

Khan, A., \& Awan, S. H. (2012). Effect of board composition on firm's performance: A case of Pakistani listed companies. Interdisciplinary Journal of Contemporary Research in Business, 3(10), 853-863.

Khumani, R. and Stone, A. \& Hurly, K. (1998), Business Environment and Corporate Governance: Strengthening Incentives for Private Sector Performance, The World Bank/IMF Annual Meetings, 1998, Background Papers.

Kiel, G. C., \& Nicholson, G. J. (2003). Board composition and corporate performance: How the Australian experience informs contrasting theories of corporate governance. Corporate Governance: An International Review, 11(3), 189-205. https://doi.org/10.1111/1467-8683.00318

Kumar, N., \& Singh, J. P. (2012). Outside directors, corporate governance and firm performance: Empirical evidence from India. Asian Journal of Finance \& Accounting, 4(2), 39-55. https://doi.org/10.5296/ajfa.v4i2.1737.

Parrotta, P., \& Smith, N. (2013). Why so few women on boards of directors? Empirical evidence from Danish companies 1997-2007. IZA Discussion Paper No. 7678. Available at SSRN: https://ssrn.com/abstract=2345595.

Pfeffer, J. (1973). Size, composition, and function of hospital boards of directors: A study of organization-environment linkage. Administrative science quarterly, 349-364. https://doi.org/10.2307/2391668

Saravanan, P. (2012). Corporate governance and company performance: A study with reference to manufacturing firms in India. http://dx.doi.org/10.2139/ssrn.2063677.

Smith, N., Smith, V., \& Verner, M. (2006). Do women in top management affect firm performance? A panel study of 2,500 Danish firms. International Journal of productivity and Performance management, 55(7), 569-593. https://doi.org/10.1108/17410400610702160

Velnampy, T. (2013). Corporate governance and firm performance: a study of Sri Lankan manufacturing companies. Retrieved from http://repo.lib.jfn.ac.lk/ujrr/handle/123456789/641.

Williamson OE (1975). Markets and Hierarchies: Analysis and Antitrust Implications. New York/London: Free Press.

Yermack, D. (1996). Higher market valuation of companies with a small board of directors. Journal of financial economics, 40(2), 185-211. https://doi.org/10.1016/0304-405X(95)00844-5. 